\title{
SCALE IN REGIONAL ENVIRONMENTAL PLANNING: THE RECONSTRUCTION OF NORTH-BRABANT, THE NETHERLANDS
}

\author{
ANDRE KOOIMAN \\ SERVIR-Africa \\ Regional Centre for Mapping of Resources for Development \\ Kasarani Road, Nairobi, Kenya \\ SUKHAD SUBODH KESHKAMAT* \\ Faculty of Geoinformation Science and Earth Observation \\ University of Twente \\ Enschede, The Netherlands \\ sukhadkeshkamat@gmail.com
}

Received 6 April 2011

Revised 15 November 2011

Accepted 23 December 2011

\begin{abstract}
Selection of scale in science and planning is often guided by ad-hoc decisions and arguments of accuracy and availability of existing data and resources. A more analytical approach to selection of scale and a bridge between theoretical insight and practical application is required. This paper reviews recent developments in thinking on theoretical concepts on scale from the perspective of geo-information science and compares these with a real life case. The concept of scale is framed as a three dimensional boundary object that explains scale choice as resultant of rationalities in reality-, model- and data scales. It is applied to a case-study of how issues of scale were handled in the Reconstruction program of the Province of North Brabant in The Netherlands. The Reconstruction is an ongoing regional spatial planning exercise that started in the year 2000 in response to major veterinary, environmental, social and economic problems in areas with concentrations of intensive livestock keeping. It combines legislation and policies at international, national, regional and municipal levels. Geographic information was produced to support and present the results of the plan process and related SEA. Scale of various intermediate
\end{abstract}

*Corresponding author. 
and final geo-information products varied from 1:5000-1:400,000 and was dependent on the plan stage, plan status and target audience, plan instrument, level of participation, data characteristics, costs and technology. By comparing theory with the case study we bring out the criteria and conditions of selection of appropriate scale whereby the usefulness of academic research in geographic information science for planning and decision making could be improved.

Keywords: Geo-information; multi-scale planning; issues of scale in spatial planning and assessment; Environment Assessment; reconstructie intensieve veehouderij (reconstruction of intensive livestock-keeping areas); North Brabant.

\section{Introduction: Scale in Planning and Assessment Practice}

Scale is one of the most overworked and yet, continuously ambiguous terms in analysis. It may be used to refer to the magnitude of a study (i.e. its extent), the degree of detail of the study (i.e. its resolution) or a means of comparing objects in a study. It has been used in the context of space, time, individuals, hierarchy, perceptions, turnover, levels of governance and more. Every discipline claims it as its own, as an intrinsic component of scientific inquiry in the discipline, with its own "universal definition" of it, thus making its use in for spatial information management multidisciplinary contexts, such as infrastructure assessment and planning, all the more difficult.

According to Quattrochi and Goodchild (1997) in the field of the geography, 5 types of scales have been identified: operational, temporal, cartographic, observational, measurement; and yet, these represent only the technical aspects behind scale choices. Cash et al. (2006b) and Lebel et al. (2005) take on the societal aspects of scale choice, observing that "scale represents a class of key choices, commitments and constraints that actors contest or are forced to accept". Karstens et al. (2007); Karstens (2009) takes on the managerial and political aspects of scale choice to show how problems can be magnified or shifted by political decisions taken to solve small scale problems without a full analysis.

In common day to day practice, however, practitioners in the fields of assessment, planning and governance must face different types of scales concurrently some explicit, others not so explicit, some as technical limitations, some subjective, yet others statutory - and make the best choice, or combination of choices, from amongst them. The choices that they make influence the quality of information and alternatives that they will ultimately deliver to the decision making process (Cash et al., 2003, 2006a). This choice is often based on a negotiation and compromise between different rationalities at play in the situation. Diesing (1962) offered an understanding and classification of such rationalities, which can be applied to any practical context. These rationalities are economic, 
social, legal, technical and political. Sager (1999) connects rationality to core questions in land-use planning:

(1) How to rationally select which kind of rationality to apply?

(2) Can rationality types be utilized simultaneously? If so, how?

(3) What is required to switch easily between rationality types?

Although we would be well advised to ask these questions at the outset of planning process, in most situations, proponents specify the level, and practitioners zero down to a certain scale based on the "most workable" solution that can be expeditiously arrived at within given resources. Several planners and impact assessment professionals, especially those working in developing countries, agree that in addition to political rationality and institutional capacity, availability of data of appropriate quality is often the driving rationality (Paliwal, 2006; Coskun and Turker, 2010; Wood, 2003), rather than the other way round. Data availability, strong institutional support, systematic information management and a fine meshing of all these is a rare luxury in practice. It is also a problem that, information which is salient and legitimate to a certain audience at a certain scale, will generally not be so at a different scale - either higher or lower (Goodchild, 2011). There are different stakeholders at different scales and so also are their concerns and priorities different at different levels. Making an appropriate choice of scale is thus a core issue that inevitably turns up in practitioner work-agendas. The reconstruction process of the province of Brabant in the Netherlands offers a notable example of how a detailed top-down and bottom-up approach were merged into complex multiscalar, multilevel outcomes that are capable of evolving over time, to address newer upcoming issues that arise in the specific sectors.

The reconstruction process has received a lot of attention along its way, much of it journalistic and some scientific publications. However, it is interesting to note that very little of this attention highlighted the spatial information components, although it was virtually the technological - GIS based - backbone which enabled the entire assessment, participation, planning, and negotiation processes. This article aims to unravel the practitioners' scale choices using a boundary object on scale choice, whose component dimensions are reality, model and data.

\section{Background of the case study}

The province of North Brabant, one of the 11 provinces of The Netherlands, lies in northwest Europe at the hub of industrialized Europe. Of the $5,000 \mathrm{~km}^{2}$ region about $11 \%$ consists of towns and cities, $26 \%$ are ecological zones and the remaining $63 \%$ is agriculture or agricultural industries. 
From the late 70s onwards, intensive livestock rearing farms, housing several thousand pigs each, or tens of thousands of chickens on (relatively) smaller parcels of land began dominating the economic structure and growth of this province. In recent years however, this practice came under threat when several livestock epidemics broke out in quick succession. The 1997 the outbreak of swine fever resulted in the culling of all the pigs on 1800 farms, at an estimated loss of $€ 2$ billion. In 2001 followed the foot-and-mouth outbreak, due to which 260,000 cattle at 2900 farms had to be culled. Aviary influenza, with similar poultry culling, followed in 2003 and 2005. Most recently in 2006, blue tongue fever and Q-fever broke out and resulted in the first human casualties. The enormous human, animal and economic costs of these outbreaks led to an awareness, both at the Dutch and European levels that the animal husbandry sector in this region had developed in a manner unacceptable to society (Hart, 2005).

Authorities realized that a major effort was required to balance the spatial claims of these interests in an integrated manner. Nationwide, a consensus developed that a major reconstruction of the rural areas in North Brabant, and other Dutch provinces with a sizable intensive livestock sector, was required. This led to the drafting and approval of the Reconstruction Act by Dutch Parliament in the year 2000, which came into effect in 2002. Environmental issues on ammonia, particulate matter, stench and the nature conservation policy, which were already mandated by European Union (EU) regulations, were linked to the reconstruction law to enable an integrated approach (Hart, 2005).

The main objective of the Act, which covered the provinces of North Brabant, Gelderland, Overijssel and Limburg (Figure 1) was the development of a proper spatial structure, especially in relation to agriculture, nature, forest, recreation, water, environment and infrastructure. However, the goals also included the improvement of quality of life, work and alternative economic opportunities for the people. Specifically, it also included the coordinated and integrated, definition and implementation of activities that would improve:

- The spatial structure of the agricultural sector in order to reduce veterinary risks associated with a high livestock density,

- The natural areas and the countryside,

- The quality of environment and water and,

- The rules regarding public health, economic structure and social services.

\section{A boundary object for scale selection}

Keshkamat (2011) proposed a framework to understand, explain and/or negotiate the process of scale selection in research and practice. The framework (Fig. 2) serves as a 


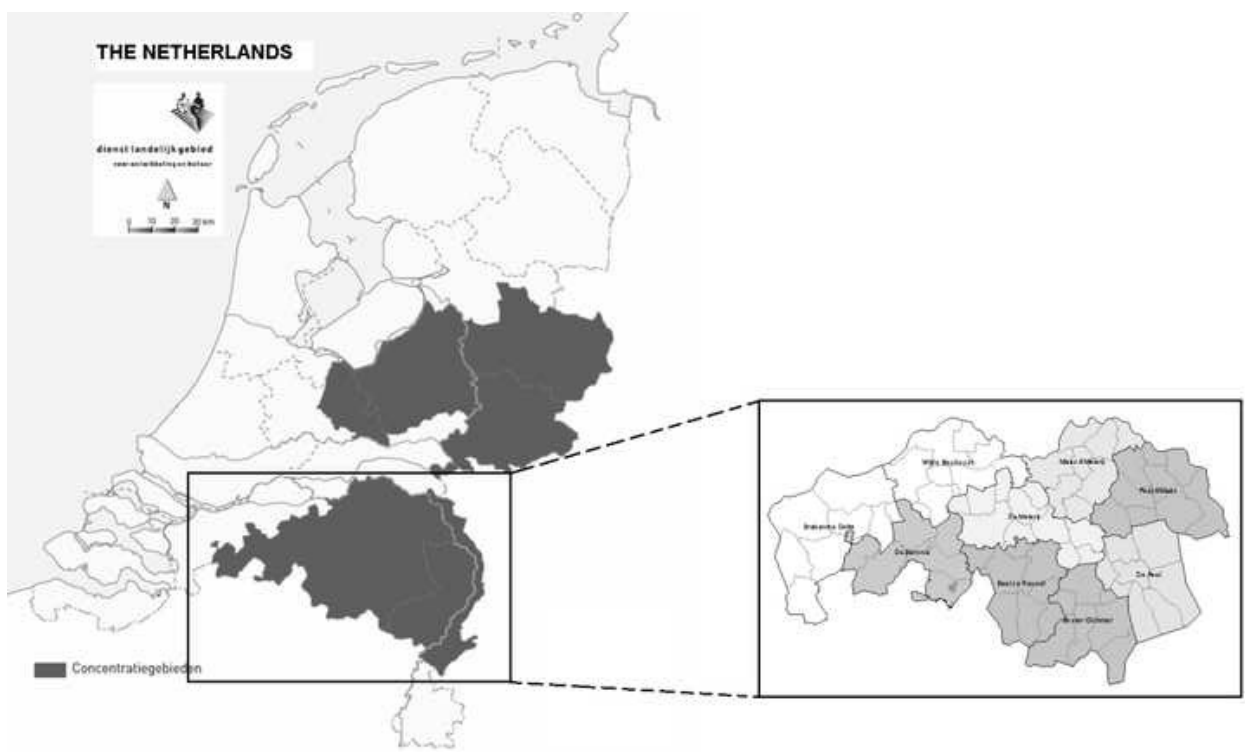

Fig. 1. Areas of the Netherlands covered by the reconstruction act and detail of province North Brabant (source: VROM, 2003).

boundary object Star and Griesemer (1989) which can be applied in the inter- and transdisciplinary context (as defined by Baumgärtner et al., 2008) required by a complex study. It was proposed by Keshkamat (2012) that this boundary object can be used in cases where the relevance, credibility and legitimacy of the process and decisions is substantially influenced by the practitioners' scale choices.

Scale can be represented as a framework of three interdependent axes:

(1) The scale of reality - framing an "observation window in which it is decided which problems, policies and legislations should be extracted and addressed.

(2) The scale of models - applying legislation and stakeholders' concerns to appropriate spatial models, and,

(3) The depiction and depiction scale, including scales of maps etc.

The interactions between these axes are described as three facets:

(4) Theory facet, representing the interaction between reality and model scale, where the researcher/analyst chooses which/how much part of the system should be studied and modeled and at what detail.

(5) Empirical facet, representing the interaction between model and data scale, where data scale is linked to the model scale which converts collected data to information by adding meaning and interpretation to otherwise neutral facts. 


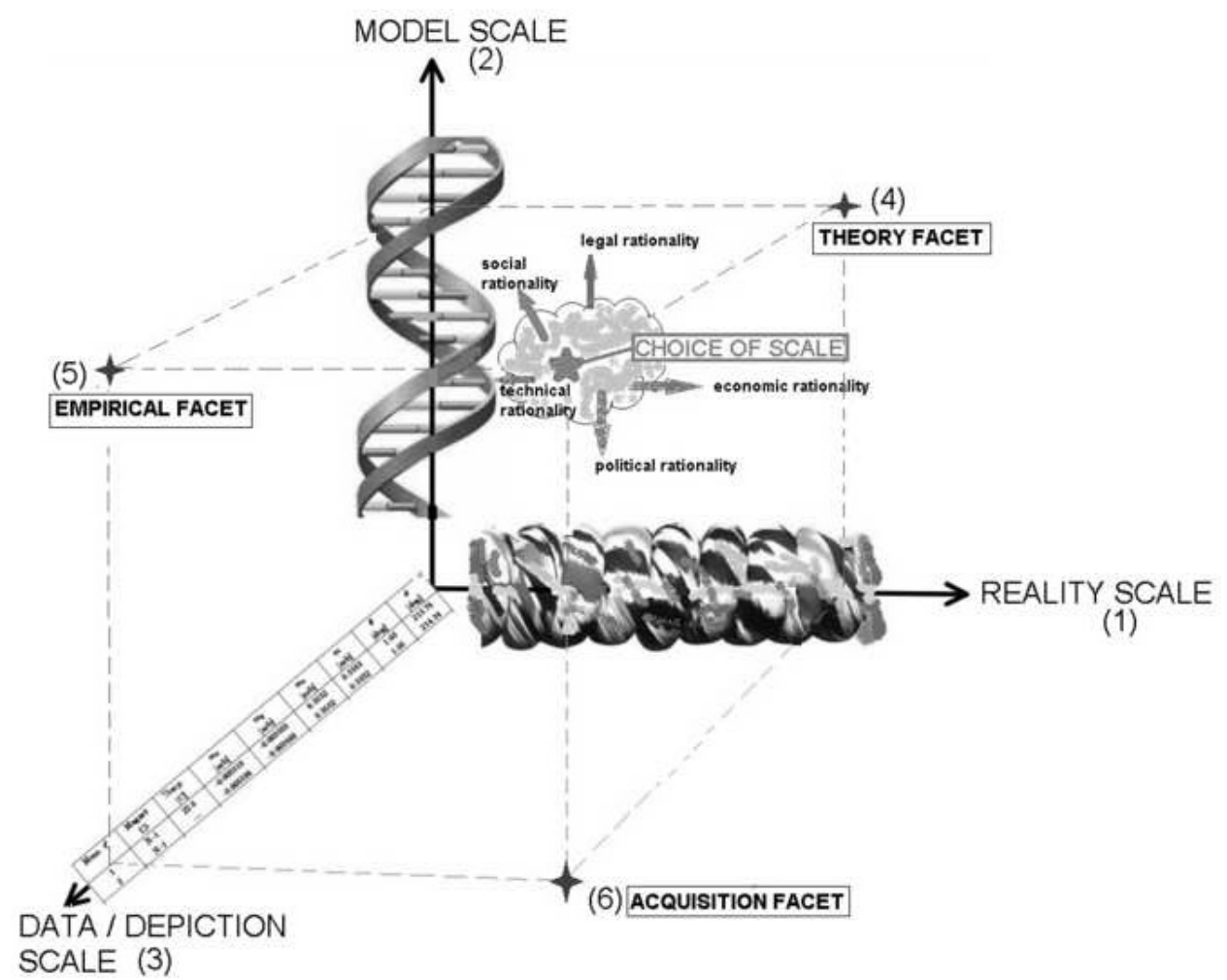

Fig. 2. A boundary object framework for scale selection (adapted from: Keshkamat, 2012).

(6) Acquisition facet, representing the interaction between reality and data scale. Aspects of scale in primary data collection, sampling strategies, costs, and other aspects of access to data, copyright, privacy issues link to this facet.

Technical, social, economic, political, legal rationalities guide the ultimate choice of scale in each facet. In the following section it will be shown how practitioners in this case-study made their scale choices in a similar step-wise manner.

The planning framework of the reconstruction process took a tiered structure implemented at different levels. Figure 3 shows the different tier-level combinations that were dealt with, with scale selection for each set of reality, model and depiction in the plan tier.

Reconstruction planning as described in this paper focused on the plan tier. For that tier however, it included several lower levels — to facilitate public participation and legal procedures - and higher levels — to facilitate linkages with guidelines and goals of higher authorities. As a result cross-tiering, cross-checking and multiscale approaches were required for the production of related spatial information. 


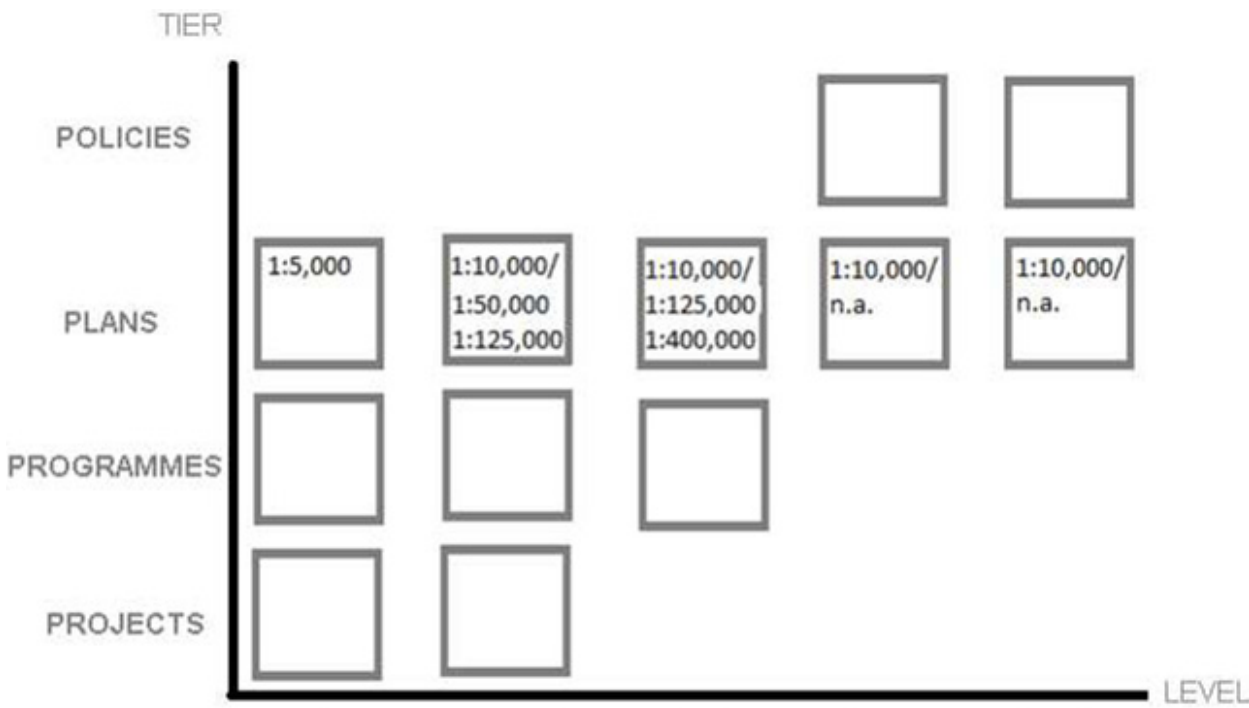

INDIVIDUAL REC. COM PROVINCE NATIONAL EU

\section{Notation: figures before slash: reference scale (accuracy), after the slash: representation scale of printed maps. N.a.: only digital maps provided}

Fig. 3. Tiers and levels in the process.

\section{The Planning Framework}

The reconstruction required a systematic structural setup, and so the assessment and planning was not only spatial, but also institutional by nature and involved a multi-level, multi scale approach. The actions needed to be supported by legislative processes, and aided by spatial information inputs at each step. At the level of the provincial planning strategic environmental assessments (SEA) formed part of the plan process. In later stages, from 2009, environmental impact assessments (EIA) were conducted for the development of individual areas and projects. Figure 4 shows a simplified timeline of the key steps in the development of the reconstruction plan following some major veterinary events that triggered the societal and legislative response.

Table 1 gives the scale of typical spatial information products for corresponding stages of the plan process. Reference scale refers to scale of the topographic base map, whereas presentation scale refers to the scale in which the map products were presented. Reference scale was determined by the choice of the appropriate topographic base-map or cadastral map layer. The presentation scale ranged between 1:400,000 for maps accompanying the umbrella plan which 


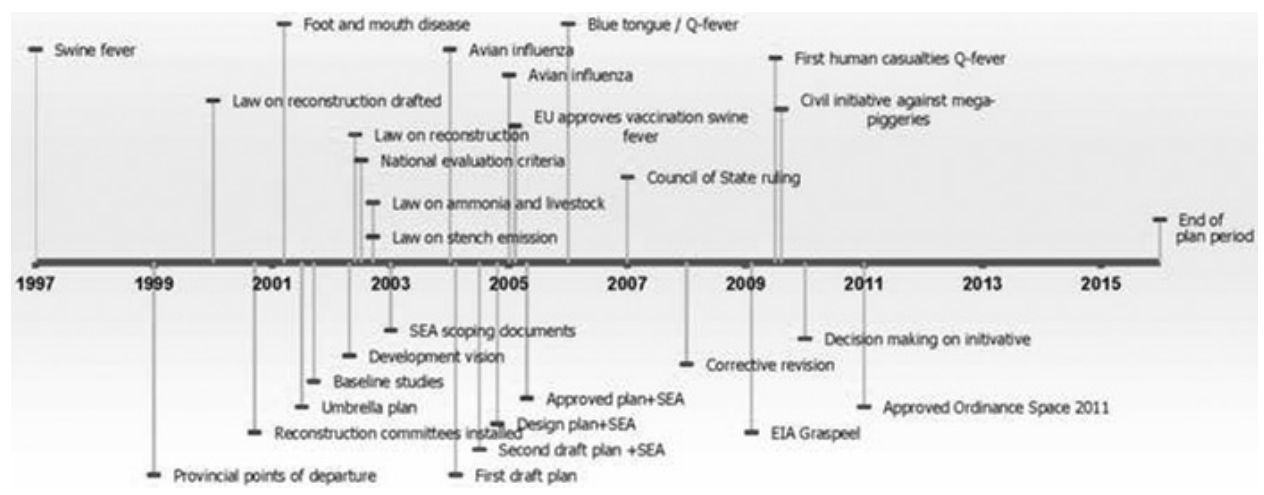

Fig. 4. Timeline of relevant events in the Reconstruction process.

provided the initial guidelines for the plan-process at the start of reconstruction, to 1:5,000 maps that were produced in the "corrected revision", 2008, in response to the council of state ruling in 2007. For every step in the plan process, GIS operations were applied to build thematic information layers at the proper accuracy, to combine these with the appropriate base-map and to create the final spatial information products at the best scale (-range). Detail was adjusted based on the requirements of the stage of the plan process. For instance, detail was maximized, for the production of the draft proposal by advisory boards and reduced for the production of development visions by reconstruction committees.

\section{Institutional setup and organization}

The Reconstruction Act, which was drafted at the national level, made the provincial governments responsible for the overall spatial framework and environmental problems of provincial interest (VROM, 2003). The law required that provinces institute a competent authority and play a directing role. Thereby the plans of higher level authorities are to be incorporated in the town and country plans of lower authorities, which should in turn integrate higher level policies with their own priorities (Padt, 2006). This nested hierarchy is an example of what Hajer and Zonneveld (2000) labeled a "Matroushka" system of interrelated strategic plans on three levels of government, and is typical for Dutch spatial planning.

Considering the legitimacy-requirements of the plan process, and the need to include diverse local concerns, circumstances, ideas and initiatives within the targets of policy and legislation at the larger scale, a participative approach was developed. In the province of North Brabant the provincial scale of implementation was considered too coarse for the intricate balancing of such an array of local interests. On the other hand, 67 municipalities planning at the local level 


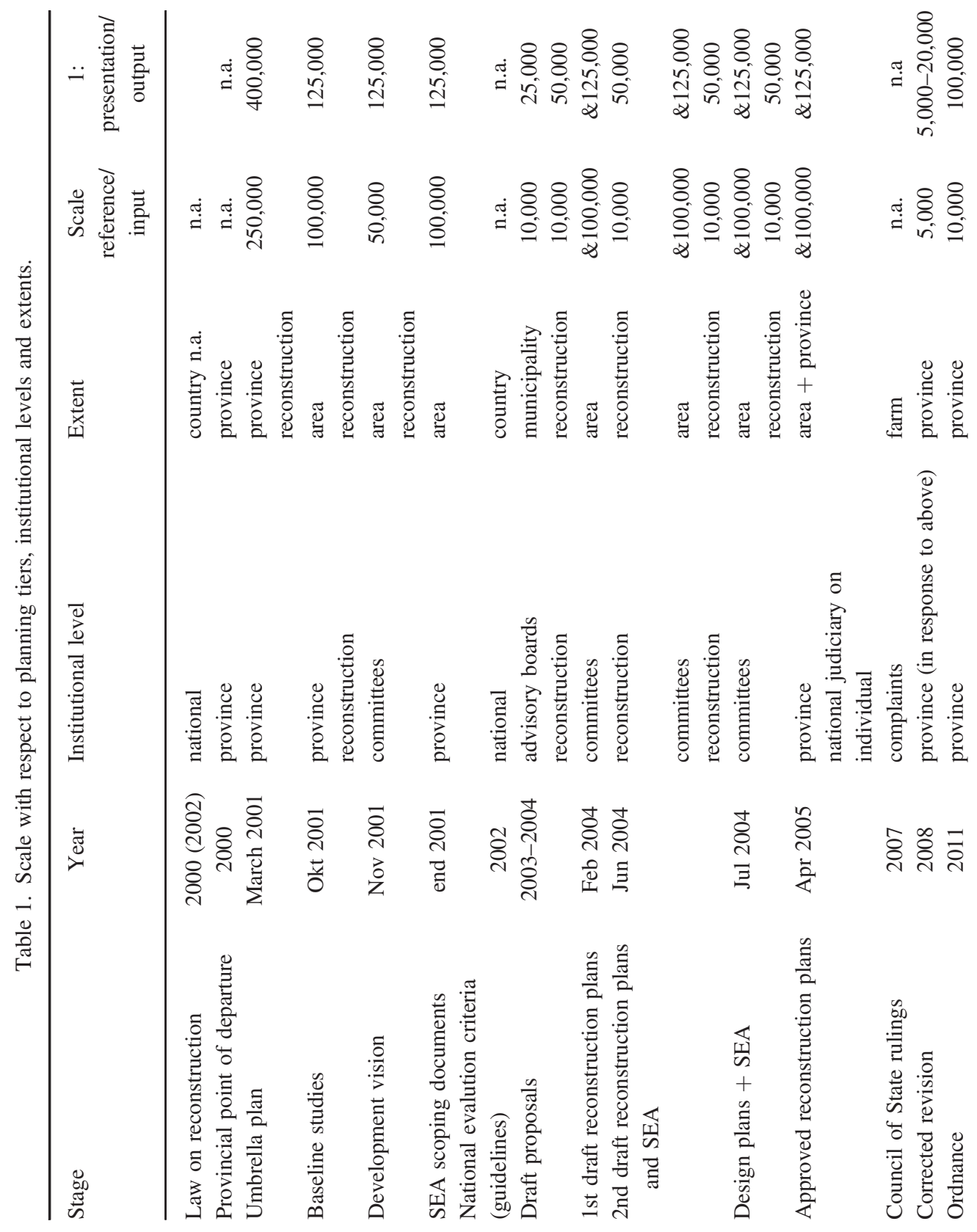


would create an unpractical number of stakeholders. Furthermore there was the lack of capacity for rural planning at many of the local governments (Provincie Noord-Brabant, 2005a). Therefore it was decided to divide the province into nine areas of seven to eight municipalities each.

In each area the provincial government installed a reconstruction committee to advise provincial authorities on the plan development and SEA, to ensure communication with stakeholders and their active participation. The reconstruction committees included representatives from provincial and national government (in advisory positions), water boards, the municipalities, farmers' unions, environment and nature, landscape and recreation sectors. In addition, stakeholder groups at every municipality constituted one advisory board, which had representatives from the same sectors and institutions, to act as a sounding board. Several advisory boards of interested and knowledgeable groups and persons were established (around 150 people/organizations per reconstruction area) to advise reconstruction committees, to channel public perceptions and ensure local support. The reconstruction committees were responsible for developing the reconstruction plans, which were then to be approved by the provincial executive council. National level organizations were involved as budget holders for impact-studies. Relevant EU level regulations were incorporated in the process, thus providing assessment criteria and opportunities to fund elements of the program. Figure 5 depicts the institutional setup along with the complex multi-level interactions graphically.

Guidelines, instructions and input information flowed from EU and national level institutes, to the provincial authorities to be passed on to the reconstruction committees. Raw plan information from the lowest participation levels flowed back to the provincial government. Processed plan information flowed from the provincial organization to both lower and higher hierarchical levels. At the provincial level a project unit was established that advised provincial council, supported reconstruction committees, coordinated planning and project implementation and developed the spatial information management program. This institutional setup enabled the program to best integrate policies and legislation at all levels. It was the basis for the definition of the users of the plans and corresponding spatial information, and the related scale (see Fig. 3).

\section{Legislation and instruments}

In order that it should not breach any existing laws and open fronts for litigations which could bog down the process, the reconstruction plan with its SEA was to fit into current policies and yet anticipate policy that was still being developed. Legislation spelled out planning instruments through which policies have to be 


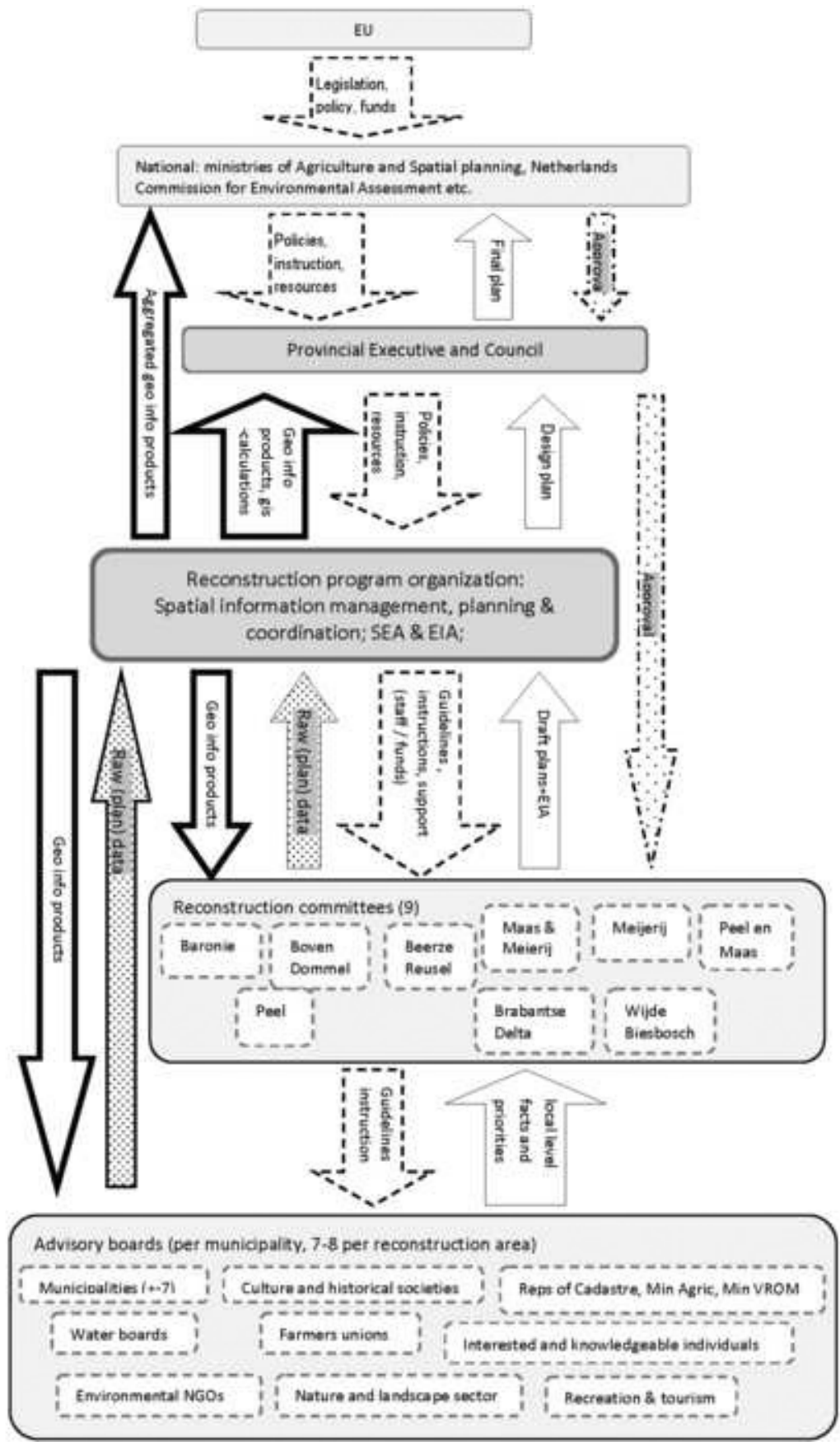

Fig. 5. The institutional framework. 
implemented. Dutch policy is constantly changing in response to awareness of problems, opportunities and public pressure at international (especially EU), national, provincial and local levels. As legislation follows suit with policy, reconstruction processes had to be flexible enough to incorporate change in policies. In the original reconstruction plans policies as of spring 2004 were considered and subsequent developments incorporated into later adjustments of the plans.

The reconstruction plans combined spatial and environmental legislation and policies. Together with the spatial planning law (Infomil, 2010) and legislation on environmental impact assessment (VROM, 1994), the most important framework legislation for the reconstruction process is the Reconstruction law 2000 (Staat der Nederlanden, 2002). It describes which existing legislation and policies are considered, and which themes relate to the regulatory spatial instruments that legally bind both the Municipal Town and Country Plan (MTCP), and the Provincial Town and Country Plan (PTCP) (Provinciale Staten van Noord-Brabant, 2004). The most important instrument is the Integrated Zoning (IZ) instrument which specifies land use zones, possibilities and allowable intensities for livestock-keeping in these zones. It has legal powers to instruct and overrule the existing MTCPs and PTCP.

In addition, the reconstruction plans include goals and aims in the environment, social and economic sectors. To achieve these goals, stimulating instruments like subsidies for land use change, land mobility, management support and support for translocation or termination of intensive livestock activities were also planned. Table 2 presents the prominent sectors, themes and corresponding legislation and policies illustrating the representation of legislation and policies from different institutional levels in the spatial planning instruments. The legally binding instruments, like IZ, had to be delineated at "parcel level", whereas instruments that were stimulatory by nature are not linked to spatial planning legislation and could be represented at global scale levels (Provincie Noord-Brabant, 2001b). Thus the legislative and policy framework addressed a wide range of spatial and spatio-temporal scales of ground-reality.

\section{Main themes and models}

The previous sections discussed the scales in institutional and legislative organization. However due to the holistic multi-sectoral nature of the planning, the various themes and environmental models associated with the sectors also had to have a multi-level framework. The reconstruction aimed at the achievement of several detailed goals over 3 five-year periods. Too minute to enumerate here, they can be thematically divided as shown in Table 3, and are reflected in the product outputs. 
Scale in Regional Environmental Planning

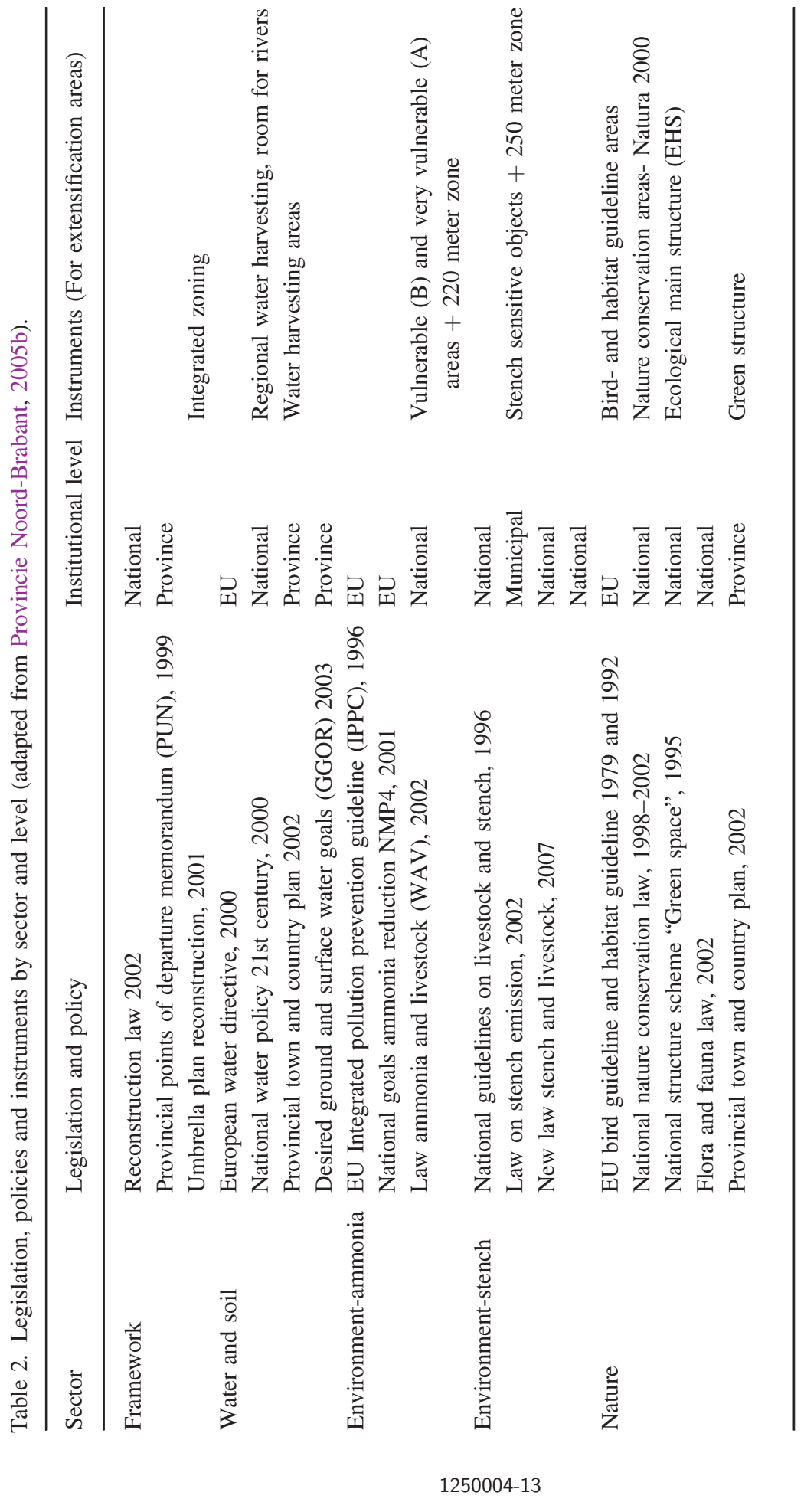


Table 3. Sectors and themes.

\begin{tabular}{ll}
\hline Sector & \multicolumn{1}{c}{ Themes } \\
\hline Water and soil & $\begin{array}{c}\text { water storage, water goals and groundwater levels, water } \\
\text { and soil quality, streams, room for rivers } \\
\text { ammonia, stench, noise } \\
\text { Environment } \\
\text { ecological structure, green structure, corridors, species } \\
\text { protection } \\
\text { Landscape and cultural history } \\
\text { Agriculture }\end{array}$ \\
$\begin{array}{l}\text { conservation and restoration, landscape quality; } \\
\text { veterinary vulnerability, spatial structure of intensive } \\
\text { livestock keeping, of glasshouse agriculture and land- } \\
\text { based agriculture, broadened agriculture, sustainable } \\
\text { production }\end{array}$ \\
$\begin{array}{c}\text { Tourism development, spatial planning of facilities and } \\
\text { infrastructure } \\
\text { Recreation and tourism }\end{array}$ \\
$\begin{array}{c}\text { agricultural economy, employment, social quality, traffic } \\
\text { and transport }\end{array}$ \\
\hline
\end{tabular}

There were several environmental models which were used to address noise dispersion, ammonia deposition, nitrate and phosphate balance, species distribution, farm stench production and public health and epidemiology. Parts of the outputs of the environmental models were used to identify criteria for the IZ and impact assessment models.

\section{The IZ model}

IZ was designed to be the instrument through which a number of these thematic goals were to be achieved. IZ translated the laws and policies at various levels into a set of spatial planning guidelines that were presented as criteria and spatial data layers. These were analysed with GIS and mapped at different scales. The GIS analyses enabled the early and accurate spatial assessment of potential synergies and conflicts of the legislations on the ground. The aim of the maps was to depict the areas described in the IZ, whereby the corresponding legislation was operationalised. The primary zones are urban, extensification, interwoven and agricultural development (Provincie Noord Brabant, 2005). The development of the zone descriptions also reflects the plan process - the negotiated compromises and adjustments of the criteria and their spatial representation by stakeholders during the plan process.

- Urban: Areas with urban functions. These were excluded from the reconstruction process. 
- Extensification: Areas where expansion, re-location and establishment of intensive livestock farms are impossible, or will be made impossible during the reconstruction.

- Interwoven: areas where the agricultural, living and nature functions are combined. Re-allocation or expansion of intensive livestock keeping is possible as long as the spatial quality of the other functions in the area is not affected.

- Agricultural development areas are predominantly agricultural areas where possibilities already exist, or will be created, for expansion, re-location or new establishment of intensive livestock farms. New establishment of intensive livestock farms can only be allowed when strict conditions are met and when all remaining agricultural development area has been fully utilized. These areas are sub-categorized into:

- Primary agricultural development area: In these areas, development of new intensive livestock farms can take place.

- Primary agricultural development area with thicket-bird and badger habitat: These are areas that overlap with habitats for thicket birds or badgers as per the provincial town and country plan (2002). In these areas intensive livestock keeping is only possible if habitat of these species can be preserved undisturbed and if landscape structure is strengthened.

- Secondary agricultural development area: These are agricultural development areas which overlap with vulnerable functions:

- 1000-1500 m buffers around EU-protected bird- and habitat guideline and nature conservation areas,

- potential areas for floodplain expansion,

- habitats of grassland birds and,

- potential water protection areas.

In these areas the establishment of new livestock farms is not permitted, unless legislation on or delineation of these vulnerable functions changes.

The IZ is legally binding for all other present and future MTCPs and PTCP, and therefore so important, that it had to be delineated at "parcel" level. The IZ outcomes were produced in the following steps:

(1) Based on the Reconstruction Law, sandy areas (i.e. historically the regions of active livestock keeping) were identified and included, and urban areas as in 2001, were mapped and excluded.

(2) Based on the criteria in the Umbrella plan (Provincie Noord-Brabant, 2001b), in 2003, preparatory maps of IZ were produced for each reconstruction area. 
In addition to the primary zones of the IZ mentioned above, the maps showed urban fringes, ecological main structure, nature areas for vulnerable species, areas vulnerable to acidification, intensive livestock keeping areas with their ammonia zones, and water-harvesting areas. The umbrella plan is further discussed under information management.

(3) The stench zoning was indicated separately as an indicative 250 meter buffer around stench sensitive objects based on municipal environmental licensing records. ${ }^{1}$

(4) Reconstruction committees then hand-drew the zoning they desired. Care was taken to follow existing parcel boundaries and map existing agricultural construction parcels unambiguously in one or another zone. In addition to the obligatory areas, Reconstruction committees considered other areas they wished to zone as extensification, interwoven or agricultural development areas based on current policies and data.

(5) GIS professionals then digitized the resultant maps by copying these lines into a new data-layer. The resulting map formed the basis for the first draft plans.

(6) To ensure the reconstruction did not conflict with PTCP of 2002 (Provinciale Staten van Noord-Brabant, 2004), they were matched and compared, especially for future rural-to-urban transformation zones. Recent adjustments in the delineation of the ecological main structure, following council of state rulings were also included. The delineations by the reconstruction committees were assessed by the Provincial Council against EU regulations on habitat- and bird-guideline areas, national rules on ammonia zones, provincial regulations on green zones, reservation areas for rivers and floodplains and water harvesting areas.

(7) Upon the conclusion of these steps, the design plan was published for public review in 2004.

(8) An adjustment in the criteria and categories of agricultural development area and approved adjustments, as proposed by the review, were included in the approved reconstruction plan in 2005 .

This shows how the planning, even in the preparatory stages was at a fine cartographic scale to match the detail at parcel level as required by the enacted spatial planning instrument. However, to facilitate holistic decision making by the Provincial Council and obtain approvals at the national level, the plans of the reconstruction areas were aggregated into one data layer for the entire province, thus sacrificing the level of detail, for extent.

\footnotetext{
${ }^{1}$ This figure was obtained by municipalities from environmental licensing and not by spatial regulation. Therefore this zone did not have the same legal status as other themes that make up the extensification areas.
} 
Assessment models

The environmental assessments in reconstruction planning were carried out at different scales that related to the level of decision making and the plan phase. They incorporated various sectoral models as mentioned previously. The initial SEAs were carried out in accordance with the law on environmental impact assessment on the first draft plans of the reconstruction committees (Kant et al., 2004). The SEAs described impacts of several alternatives that were incorporated in the subsequent planning versions. Yet, these were conducted at the scale of reconstruction areas. Integration and aggregation was required to upscale the assessments to the provincial level.

Several assessments were carried out parallel to the IZ stream to assess the impact of zoning scenarios in the plans on achievement of provincial objectives. The studies aimed to advise and to support decision making by the provincial council and executive on rules and criteria for zoning and on approval of the reconstruction plans. At the national level similar ad hoc assessments were carried out to advise ministries and support decision making of the plans. Some examples included:

- Fact finding study, 2003: A fact finding study was undertaken to assess the consequences of IZ on the intensive livestock sector (Hart, 2003). An analysis of the number, size and economic perspective of farms in each zone was conducted.

- Plan damage: When existing interests are affected by government plans, plan damages can be claimed. IZ might affect some farmers adversely, so a study of possible plan damage claims was conducted by analyzing the number of farms in extensification area (Kooiman, 2005).

- The analysis outcome was then allocated to specific levels of government based on the underlying legislation which was responsible for the damage.

- Impact of plan changes: Impacts of changes in the delineation between different versions of the plan were assessed. Area calculations of most important plan categories and updated information on the locations and types of livestock farms kept track of achievement of aims per sector. Given the duration of the planning period (2001-2016), it was important to monitor autonomous and internal developments using the latest version of datasets in the assessments.

The SEA in the reconstruction plans considered the impacts of zoning alternatives per reconstruction area. The so called agricultural development areas included possibilities for expansion and establishment of new intensive livestock farms. For the realization of these, each agricultural development area required a separate 
plan and a detailed EIA at municipal scale (for instance, RMB and Gemeenten, 2009), as stipulated in provincial guidelines (Provincie Noord-Brabant, 2003), whereas environmental licensing may require a further EIA at the level of individual farms if that farm is to host large numbers of livestock (VROM, 1994).

In recent years public concerns about the impact of the intensive livestock sector on environment and public health have tremendously increased. This has led to increased pressure on local, but also higher level authorities to carry out studies at the local level on impacts on ammonia, endotoxins, bacteria, particulate matter before decisions are made. These are to be incorporated in future EIA studies at the program and project level.

\section{Information management}

The purpose of the spatial information management program was to integrate guidelines, criteria, thematic information and models, thus providing salient and credible information to and from stakeholders and authorities at all levels. This included defining the standards for the production of new plan information so that results of the stakeholder participation process in each of the reconstruction areas could be aggregated and integrated at the provincial level.

In addition to these visualization and aggregation functions, the spatial information management program also served a key function as an expert advisory spatial decision support system (SDSS) to the provincial executive council. This function included data analyses, generation of alternative scenarios and intermediate map products showing impacts of alternatives. It also served as the information hub to national level organizations, ministries, research institutes and the EIA commission to facilitate plan approval.

Different plan processes have different information requirements. Several GIS products (Table 3) were generated to serve these functions, mainly as printed maps, but also digital (on CDs, internet). Creation of these products involved dealing with a variety of scales - sequence (temporal scale), plan process (analytical scale), representation (cartographic scale), thematic goals (model scale), background documents (data scale), which represent the scale choices that practitioners contended with in order to provide salient and credible information. In sequence these are:

(1) Umbrella plan, 2001: This document intended to inform all professional stakeholders of the basis for the reconstruction program. It translated legal background and policy framework to the points of departure for the reconstruction planning and described the responsibilities, process and themes. Maps illustrated the multidisciplinary nature of the program and were 
presented as provincial overview of main themes (as defined in Table 1). They were printed maps at scale 1:400,000 (A3 size paper) (Provincie Noord-Brabant, 2001b). In addition the first CD-ROM was produced with a stand-alone GIS application and data catalogue with basic and thematic data-layers (Provincie Noord-Brabant, 2001a).

(2) Baseline study, 2001: Some existing data were obsolete and unsuitable for inclusion in the plan process. Due to the extended duration of the plan process updating and improving information became an ongoing effort. For example,

- Updating urban areas, urban expansion and urban-rural transition zones in MTCP.

- Data on livestock farms which formed the basis for the planning, assessments and budget estimates had to be updated annually.

- Names on national topographic maps had to be localized to aid saliency and stimulate the public participation process.

- Delineation of ecological structure and other themes, the subject of review and appeal procedures in parallel processes, had to be synchronized for changes.

Updated information was incorporated in new versions of the digital atlases with accompanying text information on the nature of changes. This was initially (up to the year 2005) mailed to stakeholders on CD-ROM. Later versions were put online.

(3) Development vision, 2002: Development visions were produced by reconstruction committees during a series of workshops and subsequent meetings in 2002. They formed the kick-off of the plan process in the reconstruction areas and were the subject of the first discussions and negotiations between stakeholders on desired developments in very general terms. Large format maps were required to allow sketching and discussion, but details were considered detrimental to the process and were removed through GIS generalization operations. Development ambitions were indicated as icons placed in approximate locations. Some basic guidelines were applied to ensure results from different reconstruction areas could be compared and aggregated to the provincial level. Large scale maps and a digital atlas of the most important themes for each reconstruction area supported the reconstruction committees.

(4) Scoping study SEA, 2002: This study prepared the SEA for the plans per reconstruction area with the provincial executive as competent authority. It included the same thematic maps as the umbrella plan but with more detail (1:125,000). The stakeholder-proposed development visions (point 3 above) were included in the scoping. 
(5) First draft plans were prepared by reconstruction committees and presented to the province for approval during 2003. The planning was supported by detailed terms of reference per plan theme to ensure comparable approaches, details, accuracies and results in each of the 9 reconstruction areas. Each advisory board hand-drafted proposals following these terms of reference. The proposals were subsequently digitized and formed the basis for further negotiation, completion and formalization of the draft plans by the reconstruction committees.

(6) The impacts on environmental indicators of the alternatives in the first draft plans were assessed and integrated into one document per reconstruction area, containing five groups of maps: detailed and general plan maps, and maps of present situation, alternatives and impacts. The alternatives included all themes, including IZ, and were compared with present situation and autonomous developments.

(7) For each reconstruction area, reconstruction committees adjusted and adapted the preferred alternatives based on above assessments of the first draft plans and integrated them into the second draft plans.

(8) Design plans: The Province reviewed plans of reconstruction committees and considered the combined results of all plans against the criteria of the SEA's and two specific additional assessment procedures - the water and nature reviews. The plans were widely distributed and kept for public review and comment for 6 weeks. Received objections and suggestions were bundled in a Memorandum of Objections for consideration by the Provincial Executive.

(9) Final plan: In the Memorandum of Views the Provincial Executive presented its response on the Memorandum of Objections, which included about 400 public complaints per reconstruction area. Some complaints led to changes in the plans, for instance in case of errors and corrections in thematic information that followed parallel planning process and appeal procedures. All changes at parcel level (i.e. 1:10,000), were combined in a Memorandum of Amendments, which was incorporated in the final plan.

(10) After the final plan was presented, the Council of State ruled on appeals against certain aspects of the reconstruction plan. Accordingly, adjustments were required where boundaries of zones intersected with agricultural parcels and building plots (Provincie Noord-Brabant, 2008). These corrections at building plot level were made using cadastral data at the very detailed level of 1:5,000. The web version (Provincie Noord-Brabant, 2011) presents the full extent of the data using a reference scale of 1:10,000 and 2 meter accuracy. 
Scale in Regional Environmental Planning

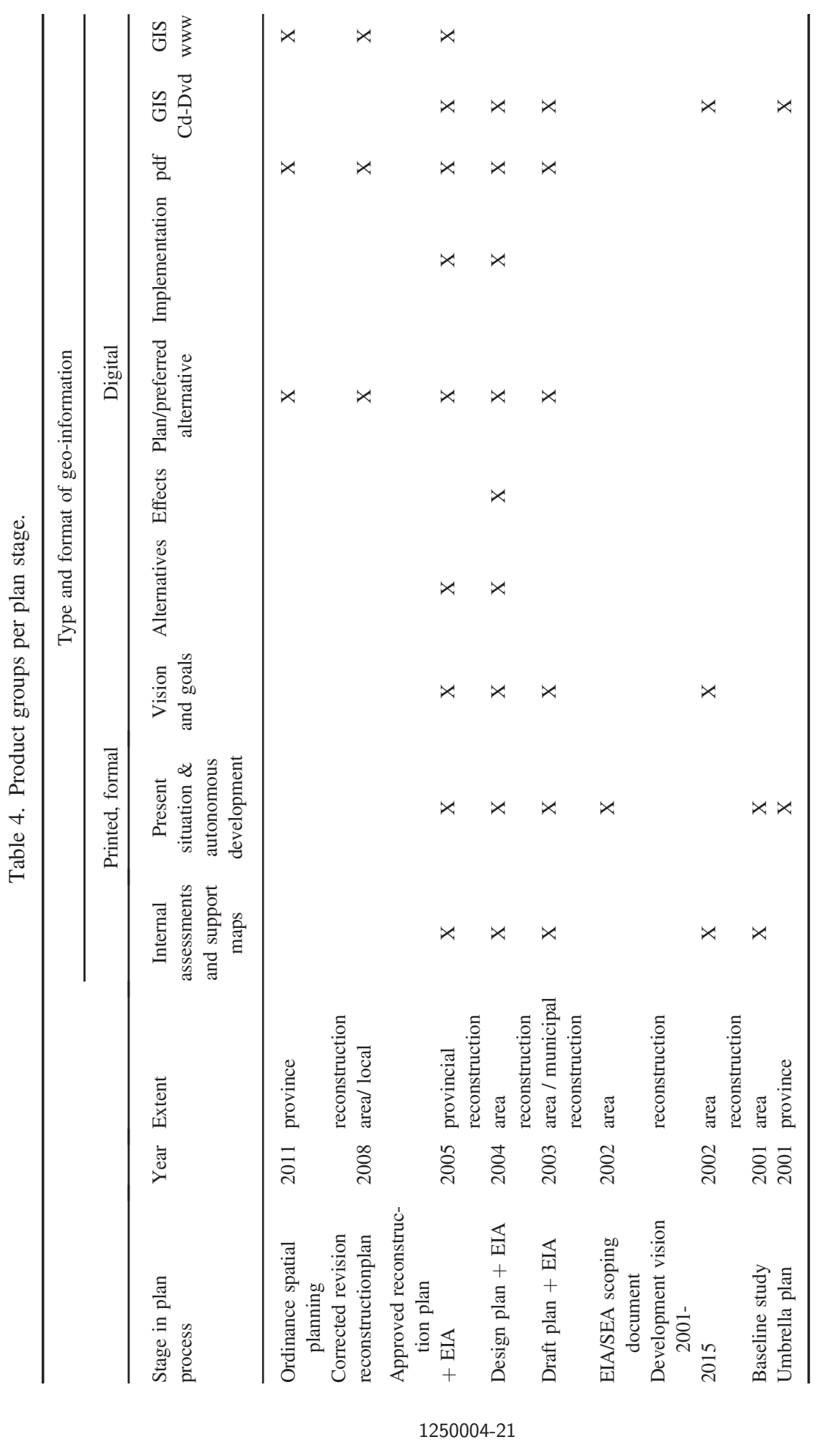




\section{Scale issues}

The choice of scale also has a very important role in providing salient information, within technical constraints and at reasonable cost. The choice of product scales had to balance quality and accuracy requirements, technical constraints and costs. For example, the support maps for Advisory Boards at municipal level were printed at large scales $(1: 20,000)$ for municipal areas as local detail was required. Support maps for reconstruction committees were presented at coarser scales of 1:50,000. However, for provincial authorities these fine scale maps could not provide the required overview and so were expanded to $1: 125,000$ by combining with the national generalized topographic layer $(1: 100,000)$. In combination with the spatial extent of the reconstruction areas, these scales could be represented on standard paper formats that enabled reproduction at reasonable cost. This was important given the large number of color maps in each plan (more than 40) and the considerable circulation of copies that was required due to the participatory nature and public interest in the planning exercise (600-900 per reconstruction area). All maps and texts were also copied onto CD-ROM to facilitate dissemination at minimal cost.

Digital material was produced in the form of a series of atlases i.e. (Provincie Noord Brabant, 2005; Provincie Noord-Brabant, 2001a). Considering the limited coverage and speed of internet connections with the general public, these were initially produced on CD-ROM/DVD. All data layers were presented at provincial level and were also made accessible via the provincial intranet. The final versions were also made available through internet at 1:10,000. Since January 2010, the spatial planning has been made fully digital which means that spatial plans are digitally prepared, approved, published and managed (VROM, 2008). Information is now made available online with a "Flamingo" data viewer — an opensource, easy-to-use, browser-based map-viewer for panning, zooming and printing (Flamingo Mapcomponents, 2006-2009). It connects to a separate download application, which facilitates sending selected data from the officially approved dataset to email addresses.

All the spatial information products, intermediate as well as final, outcomes as well as preparatory material had to be worked, so that the information was presented in a manner that presents relevant facts to its audience. This section showed how the digital spatial information and GIS tools formed the backbone that enabled practitioners to successfully manage vast amounts of spatial data, delivering the right contextual information, within technological and financial limits, to and from stakeholders, assessment professionals, authorities and decision makers, thus aiding legitimacy of the reconstruction plan. 


\section{Reflection and Discussion}

Through the description of the case study, the disciplines, multiple levels, spatial scales and temporal scales at which the assessment, planning and management (or governance) of the reconstruction took place were elaborated. Public participation took place at the grassroots level, with aggregation and assimilation of outcomes taking place at higher levels. Decisions taken at higher levels passed to lower levels for reassessment and were implemented at the mid-level (provincial). At the same time legislative support was provided to the institutional framework from top down. Although it was not apparent to the decision makers and stakeholders, in the background the spatial information, GIS, assessment procedures and the selection of scale played an important role at each step of the process. It was seen in the previous sections how practitioners in this case-study made their scale choices in a similar step-wise manner. Scales were chosen for representing reality through mathematical and spatial models, depicting reality (through maps, in this case) and generating scenarios and alternatives using the models and depicting those using maps. In this, the component of the argumentation for scale choices clearly link with the described theoretical model of scale as boundary object.

This case-study is particularly noteworthy because the scale choices were arrived at through documented iterations and multi-rational bases, which is not always the case. It was the strong GIS backbone of the Plan process that enabled the practitioners to carry out such iterations in appropriate formats and within tight time frames.

It is also pertinent to highlight here a few relevant issues of significance, albeit of secondary importance, to this plan and the scale choices. These included:

Scale of time: As seen in Fig. 4, the Reconstruction plan period was specified as 2001-2016. Over this period, even as it is being executed, the plan and its underlying spatial information layers continue to evolve, with ongoing actualization needed to incorporate autonomous developments, achievements of plan implementation and any legislative and policy changes, which were not considered before. In relation to the theoretical model this issue is related to the facet of theory.

Data ownership and copyright: Data ownership influenced access to digital data, especially the use of topographic base data. For printed material, the detailed 1:10,000 topographic map could be used. However, although it was readily available for internal access by provincial staff, copyright limited the incorporation of the digital version of this dataset on the CD-ROM that was sent to external stakeholders. A generalized version at the smaller scale of 1:25,000 was therefore 
included on the $\mathrm{CD}$ version. Though not considered desirable from the perspective of equal access to all data sources by all stakeholders, copyright limitations forced the program authorities to accept these differences.

Copyright and data access were also important in work that was contracted to external parties, for example the SEA and other impact-studies. Intermediate steps and final results of contracted work were distributed in the form of printed maps and their PDF versions. However, the original GIS equivalent of the products could not always be made available and thus was not fully verifiable by stakeholders.

Privacy Issues: The issues of data ownership and privacy typically relate to the acquisition facet as described in the 3D model. Farmers' privacy arguments were initially used to limit access to the database on livestock farms, although the origin of the database - municipal environmental licenses - was public and this information was of prime importance for all parties involved in the planning. Given the participatory nature of the plan process, this information also had to be made available to stakeholders other than government. Considerable negotiations were conducted between provincial and municipal governments to ensure that this dataset and its updates could be made available and distributed to all stakeholders in reconstruction planning.

\section{Conclusion and Future Developments}

In the preceding sections we brought out the enormous utility of GIS in spatial planning and environmental assessment in a multi scalar, transdisciplinary, multilevel environment, wherein a large number of stakeholders of varying capacities are involved. It sought to highlight the intrinsic understanding of scale that practitioners must have, and the "juggling" they must do, in order to deliver good quality information to the decision making process. Such an extensive management of information in a participatory spatial planning process, in a cost- and time-effective manner, could only be managed because of the stable spatial information backbone.

Several authors have attempted to explain and develop the theory of the selection (and impact) of scale in assessment and planning. At the same time practitioners, with their tacit understanding of scale, continue to "get the job done". To try to bridge the gap between theory and practice, we sought to take apart this tacit manipulation of scales in a complex planning framework and shelve it into reality - (legal and institutional frameworks), model — and representation frames. In practice, scale of spatial information does not strictly follow tiers and institutional levels on a one-to-one correspondence. One tier may be linked to 
several institutional levels as in this case study. Therefore some degree of iterations and cross-checking will often be required before appropriate scales are found. The use of GIS enables cost- and time-efficient multi-scalarity in such situations. Based the boundary object of Keshkamat (2012), practitioners' considerations scale can be divided into those on institutions and institutional processes which relate to the axis of reality; those on themes and criteria which relate to the model axis, whereas those regarding the acquisition and management of basic data which relate to the data axis. The interactions between these axes (facets) are the key to finding the appropriate operational scale.

We find that data issues such as temporal scales, copyright ownership, privacy and cross-scale manipulations, although very important, are being dealt with separately from the main issues. We also find that if the provision of good quality information to decision-making follows the 3 precepts of salience, credibility and legitimacy, spatial data and GIS can form an indispensable tool for environmental assessment, spatial planning and stakeholder engagement processes. Making an appropriate choice of scale in analyses, modelling, data collection and representation plays an important role in the quality of information that will be provided.

\section{References}

Baumgärtner, S, C Becker, K Frank, B Müller and M Quaas (2008). Relating the philosophy and practice of ecological economics: The role of concepts, models, and case studies in inter-and transdisciplinary sustainability research. Ecological Economics, 67, 384-393.

Cash, DW, WC Clark, F Alcock, NM Dickson, N Eckley, DH Guston, J Jäger and RB Mitchell (2003). Knowledge systems for sustainable development. Proceedings of the National Academy of Sciences of the United States of America, 100, 8086.

Cash, DW, WN Adger, F Berkes, P Garden, L Lebel, P Olsson, L Pritchard and O Young (2006a). Scale and cross-scale dynamics: Governance and information in a multilevel world. Ecology and Society, 11, 8-8.

Cash, DW, W Adger, F Berkes, P Garden, L Lebel, P Olsson, L Pritchard and O Young (2006b). Scale and cross-scale dynamics: Governance and information in a multilevel world. Ecology and Society, 11.

Coskun, AA and O Turker (2010). Analysis of environmental impact assessment (EIA) system in Turkey. Environmental Monitoring and Assessment, 1-14.

Diesing, P (1962). Reason in Society; Five Types of Decisions and Their Social Conditions. Urbana, University of Illinois Press.

Flamingo Mapcomponents (2006-2009). Flamingo Mapviewer. 3.2 ed. 
Goodchild, MF (2011). Scale in GIS: An overview. Geomorphology, 130, 5-9.

Goodchild, MF and DA Quattrochi (1997). Scale, Multiscaling, Remote Sensing and GIS.

In Goodchild, MF and DA Quattrochi (eds.) Scale in Remote Sensing and GIS. Boca Raton, FL: CRC Lewis.

Hajer, M. and W Zonneveld (2000). Spatial planning in the network society-rethinking the principles of planning in the Netherlands. European Planning Studies, 8, 337-356.

Hart, GT (2003). Resultaten feitenonderzoek reconstructie. 's-Hertogenbosch: Provincie Noord-Brabant.

Hart, GT (2005). Het proces in vogelvlucht, PS-dossier 22 april 2005, bijlage 10 's-Hertogenbosch: Provincie Noord-Brabant.

Infomil (2010). Handreiking Ruimtelijke Ordening en milieu. Den Haag: Ministerie van Volkshuisvesting, Ruimtelijke Ordening en Milieubeheer.

Kant, P, S Eijtjes, A Spierings (Reconstructiecommissie de Peel) (2004). Reconstructieplan/MER De Peel, 1ste concept. Deel A. 58.

Karstens, S (2009). Bridging Boundaries: Making Scale Choices in Multi-actor Policy Analysis on Water Management. Deltares Select Series.

Karstens, SAM, PWG Bots and JH Slinger (2007). Spatial boundary choice and the views of different actors. Environmental Impact Assessment Review, 27, 386-407.

Keshkamat, SS (2012). The road less travelled: Scale in assessment and planning of infrastructure. Ph.D. dissertation, University of Twente, The Netherlands.

Kooiman, A (2005). Vergelijking typen intensieve veehouderij in extensiveringsgebieden. In RLG (ed.). ed. 's-Hertogenbosch: Provincie Noord-Brabant.

Lebel, L, P Garden and M Imamura (2005). The politics of scale, position, and place in the governance of water resources in the Mekong region. Ecology and Society, 10, 18-18. Padt, F (2006). Regional environmental planning in the Netherlands: An unstable settlement of policy arrangements. Institutional Dynamics in Environmental Governance, 203-223. Paliwal, R. (2006). EIA practice in India and its evaluation using SWOT analysis. Environ. Impact Assess. Rev., 26, 492-510.

Provinciale Staten van Noord-Brabant (2004). Streekplan Noord-Brabant 2002 'Brabant in Balans'.

Provincie Noord-Brabant (2001a). Digitale Atlas RLG, Deel 1. 's-Hertogenbosch.

Provincie Noord-Brabant (2001b). Revitalisering Landelijk gebied. Reconstructie aan zet. Koepelplan Reconstructie Concentratiegebieden. 's-Hertogenbosch.

Provincie Noord-Brabant (2003). Handleiding duurzame locaties en duurzame projectlocaties voor de intensieve veehouderij.

Provincie Noord-Brabant (2005a). Reconstructieplan/Milieueffectrapport Deel A: Baronie, Beerze Reusel, Boven Dommel, Maas en Meijerij, Meijerij, Peel en Maas, De Peel. 's-Hertogenbosch.

Provincie Noord-Brabant (2005b). Reconstructieplan/Milieueffectrapport, deel B: Baronie, Beerze Reusel, Boven Dommel, Maas en Meijerij, Meijerij, Peel en Maas, De Peel. 's-Hertogenbosch. 
Provincie Noord-Brabant (2008). Ontwerp correctieve herziening reconstructieplan: Baronie, Beerze Reusel, Boven Dommel, Maas en Meijerij, Meijerij, Peel en Maas, De Peel. 's-Hertogenbosch: OBT bv, Den Haag.

Provincie Noord-Brabant (2011). Kaarten Landbouwontwikkelingsgebieden [Online]. 's-Hertogenbosch. Available: http://www.brabant.nl/kaarten/ruimtelijke-ordening-kaarten/landbouwontwikkelingsgebieden.aspx [Accessed 15 March 2011].

Provincie Noord Brabant (2005). Digitale atlas revitalisering landelijk gebied (RLG) 2005. In Directie Roh, PNB (ed.). 's-Hertogenbosch.

RMB and AV Gemeenten (2009). Plan-M.E.R. bestemmingsplan LOG Graspeel. Gemeenten Landerd en Mill \& Sint Hubert. Reconstructiegebied Peel en Maas. Cuijck. Sager, T (1999). The rationality issue in land-use planning. Journal of Management History (Archive), 5, 87-107.

Staat der Nederlanden (2002). Reconstructiewet concentratiegebieden. Den Haag: SDU Publishers.

Star, SL and JR Griesemer (1989). Institutional Ecology, "Translations" and Boundary Objects: Amateurs and Professionals in Berkeley's Museum of Vertebrate Zoology, 1907-39. Social Studies of Science, 19, 387-420.

VROM (1994). Besluit milieueffectrapportage. In VROM (ed.). Den Haag.

VROM (2003). De reconstructiewet. Reconstructie en ruimtelijke ordening in de praktijk. Den Haag.

VROM (2008). GIDEON-Basisvoorziening geo-informatie Nederland, visie en implementatiestrategie (2008-2011) 56.

Wood, C (2003). Environmental impact assessment in developing countries: An overview. International Development Planning Review, 25, 301-321. 